plasma ACTH together with radiological visualization of the adrenal glands will have to be relied upon to place the lesion primarily in the hypothalamic-pituitary axis or in the adrenal.

\section{Acknowledgments}

We would like to thank Dr A. Swanepoel for referring the patient, Professor J. H. Louw who performed the operation and the Department of Chemical Pathology, University of Cape Town, for the steroid estimations.

\section{References}

Bethge, H., Winkelmann, W., Heesen, D., Mies, R., WeigelmanN, W. \& BAYER, J.M. (1971) Differential diagnosis of Cushing's syndrome by means of lysine vasopressin. Acta endocrinologica, Suppl. 152, 91.

Brookes, R.V., Jeffcoate, S.L., London, D.R., Prunty, F. T. G. \& SMITH, P. M. (1966) Intermittent Cushing's Syndrome with anomalous response to dexamethasone. Journal of Endocrinology, 36, 53.

Demura, R., Demura, H., Nunokawa, T., Baba, H. \& MurA, K. (1972) Response of plasma ACTH, GH and LH and $n$-hydrocorticosteroids to various stimuli in patients with Cushing's syndrome. Journal of Clinical Endocrinology, 34, 852.

Dingman, J.F., Finkenstaedt, J.T., LAIDlaw, J.C., Renold, A.E., Jenkins, J., Merril, J.P. \& Thorn, G.W. (1958) Influence of intravenously administered adrenal steroids on sodium and water excretion in normal and Addisonian subjects. Metabolism, 7, 608.

Drekter, I.J., Heisler, A., Scism, G.R., Stern, S., Pear-
SON, S. \& McGavacK, T.D. (1952) The determination of urinary steroids. Journal of Clinical Endocrinology, 12, 55.

FEw, J.D. (1961) A method for the analysis of urinary 17hydroxycorticosteroids. Journal of Endocrinology, 22, 31.

French, F.S., JefFreys, A.M., BaGget, B., Williams, T.F. \& VAN WYK, J.J. (1969) Cushing's syndrome with a paradoxical response to dexamethasone. American Journal of Medicine, 47, 619.

HARden, R. McG. \& Forrest, A.P.M. (1964) Cushing's syndrome with atypical biochemical results. Acta endocrinologica, 46, 256.

JAMES, V.H.T., LANDON, J. \& WYNN, V. (1965) Oral and intravenous suppression tests in the diagnosis of Cushing's syndrome. Journal of Endocrinology, 33, 515.

JAMES, V.H.T. \& LANDON, J. (1968) In: Recent Advances in Endocrinology, 8th edn, p. 65. Churchill, London.

LIDDLE, G.W. (1960) Tests of pituitary-adrenal suppressability in the diagnosis of Cushing's syndrome. Journal of Clinical Endocrinology, 20, 1539.

Martin, M.M. \& Hamman, B.L. (1966) Patterns of urinary excretion of steroids in Cushing's syndrome. Journal of Clinical Endocrinology, 26, 257.

Mattingly, D. (1962) A single fluorimetric method for the estimation of free 11-hydroxycorticoids in human plasma. Journal of Clinical Pathology, 15, 374.

Ross, E.J., Marshall-Jones, P. \& Friedman, M. (1966) Cushing's syndrome: diagnostic criteria. Quarterly Journal of Medicine, 35, 149.

Vermess, M., Schour, L. \& JAfFe, E.S. (1972) Calcification in benign non-functioning adrenal adenoma. Report of a case with selective adrenal arteriogram. British Journal of Radiology, 45, 621.

\title{
Acute renal failure complicating McArdle's syndrome
}

\author{
P. M. FORD \\ M.B., M.R.C.P.
}

\author{
W. R. C. WEIR \\ M.B., Ch.B.
}

\author{
A. A. H. Manugian \\ M.B., Ch.B.
}

Dundee Royal Infimary, Dundee, DD1 9ND

\section{Summary}

A case of McArdle's syndrome is described in which an epileptiform seizure was followed by acute reversible renal failure with hypercalcaemia in the diuretic phase.

\section{Introduction}

McArdle's syndrome is a rare disorder of muscle metabolism which presents in early life with pains and stiffness in the muscles during exercise. The disorder is known to be due to muscle phosphorylase deficiency (Schmid \& Mahler, 1959) and behaves as an autosomal recessive. Myoglobinuria is known to occur during attacks, but acute oliguric renal failure has been reported in only two patients (Grünfeld et al., 1972). We report a further case of renal failure associated with McArdle's syndrome with the added complication of hypercalcaemia occurring during the diuretic phase.

\section{Case report}

The patient, R.G., previously reported in a family study of McArdle's syndrome (Salter, 
Adamson \& Pearce, 1967) first presented in 1961 at the age of 16 years with stiffness and weakness of the legs on exertion. These symptoms continued and during the next 3 years the patient had three episodes of loss of consciousness associated with the passage of dark urine. In 1964 the urinary pigment was identified as myoglobin and subsequent muscle biopsy showed the changes characteristic of McArdle's syndrome (Pearce, 1965). The attacks of unconsciousness were considered to be epileptiform seizures, and phenobarbitone was prescribed. Several further fits again associated with pigmenturia were noted over the next few years.

In August 1972, R.G. was admitted for observation after losing consciousness and falling 10 feet from a ladder. He was noted at the time to be passing dark urine and spectroscopic examination suggested that the pigment was methaemoglobin. He was discharged apparently well after $36 \mathrm{hr}$. One week later he was re-admitted complaining of nausea, malaise, oliguria and swelling of the ankles and face. Physical examination revealed mild facial swelling, slight sacral oedema, but no ankle oedema. Pulse rate was $80 / \mathrm{min}$, and normal in character, blood pressure $130 / 90 \mathrm{mmHg}$, there was no jugular venous congestion and heart sounds were normal. Crepitations were heard in the lower lobes of both lungs. Other systems appeared normal.

\section{Investigations}

Plasma sodium $135 \mathrm{mEq} / \mathrm{l}$, potassium $5.8 \mathrm{mEq} / \mathrm{l}$, chloride $86 \mathrm{mEq} / \mathrm{l}$, bicarbonate $19 \mathrm{mEq} / \mathrm{l}$. Blood urea $510 \mathrm{mg} / 100 \mathrm{ml}$, blood sugar $208 \mathrm{mg} / 100 \mathrm{ml}$, serum calcium $8.4 \mathrm{mg} / 100 \mathrm{ml}$, serum phosphate $11.1 \mathrm{mg} / 100 \mathrm{ml}$, alkaline phosphatase 6 KingArmstrong units, serum urate $17.7 \mathrm{mg} / 100 \mathrm{ml}$ and serum creatinine $16.8 \mathrm{mg} / 100 \mathrm{ml}$. Haemoglobin was $11 \cdot 1 \mathrm{~g} / 100 \mathrm{ml}$, white cell count $9800 / \mathrm{mm}^{3}$, with normal film.

Initially the patient was completely anuric and no urine was therefore available for examination.

\section{Progress}

Peritoneal dialysis was required for 5 days after which diuresis ensued and the blood urea slowly fell. The only medication at the time was phenytoin, and the patient received a diet containing $20 \mathrm{~g}$ protein/day. On the tenth day following admission bilateral episcleritis was noted and the serum calcium was found to be $12.3 \mathrm{mg} / 100 \mathrm{ml}$ and phosphate $7.7 \mathrm{mg} / 100 \mathrm{ml}$. Slit lamp examination of the eyes was, however, normal. A week later the calcium had fallen to $9.7 \mathrm{mg} / 100 \mathrm{ml}$ and the eye signs had resolved. Three weeks after admission the patient was discharged with a blood urea of $41 \mathrm{mg} / 100 \mathrm{ml}$ and a creatinine clearance of $40 \mathrm{ml} / \mathrm{min}$. Blood urate, calcium, phosphate and alkaline phosphatase were within normal limits.

\section{Discussion}

Acute renal failure complicating McArdle's syndrome would appear to be rare, only two previous cases having been reported (Grünfeld et al., 1972). Renal failure associated with myoglobinuria, however, is a well recognized entity and has been described in association with crush syndrome, exercise induced myoglobinuria and primary paroxysmal myoglobinuria. Presumably the severe muscle exertion of a grand mal seizure which is a recognized association of McArdle's syndrome (Salmon \&. Turner, 1965) in our patient caused a degree of muscle breakdown sufficient to release a toxic quantity of myoglobin. The reason why the urinary pigment was not identified as myoglobin may be due to the fact that myoglobin readily converts to the met form which is difficult to distinguish from methaemoglobin spectroscopically (Muehrcke, 1969). The occurrence of hypercalcaemia during the diuretic phase was a feature of one of the cases of Grünfeld et al., and has in addition been reported in seven cases of acute renal failure associated with severe muscle or soft tissue injury, where it also occurred in the diuretic phase (Leonard \& Nelms, 1970). Although the authors were unable to explain this phenomenon they did note an elevation of parathormone in one of the two patients in whom it was assayed. It is, however, known that in the experimental animal acute renal failure may cause the deposition of large amounts of calcium in areas of necrotic muscle (Meroney et al., 1957). Bütikofer \& Molleyres (1968) suggest that the hypercalcaemia may be due to subsequent reabsorption of calcium from such areas. No specific treatment would appear to be indicated for the hypercalcaemia as it appears to resolve spontaneously.

\section{Acknowledgment}

We are grateful to Dr W. K. Stewart for permission to report this case.

\section{References}

Bütikofer, E. \& Molleyres, J. (1968) Akute ischamische Muskelnekrosen, reversible Muskelverkalkungen und sekundare Hypercalciamie bei akuter Anurie. Schweiz Medizinische Wochenschrift, 98, 961.

Grünfeld, J.-P., Ganeval, D., Chanard, J., Fardeau, M. \& DREYFUS, J.-C. (1972) Acute renal failure in McArdle's disease: report of two cases. New England Journal of Medicine, 286, 1237.

LeONARD, A. \& Nelms, R.J. (1970) Hypercalcaemia in diuretic phase of acute renal failure. Annals of Internal Medicine, 73, 137.

Meroney, W.H., Arney, G.K., Segar, W.E., \& Balch, H. (1957) The acute calcification of traumatized muscle, with particular reference to acute post traumatic renal insufficiency. Journal of Clinical Investigation, 36, 825.

MUEHRCKe, R.C. (1969) Acute Renal Failure: Diagnosis and Management, p. 197. C. V. Mosby Co., St Louis. 
Pearce, G.W. (1965) Histopathology of voluntary muscle. Postgraduate Medical Journal, 41, 294.

Salmon, S.E. \& Turner, C.E. (1965) McArdle's disease presenting as convulsion and rhabdomyolysis. American Journal of Medicine, 39, 142.

Salter, R.H., Adamson, D.G. \& Pearce, G.W. (1967)
McArdle's syndrome (myophosphorylase deficiency). Quarterly Journal of Medicine, 144, 565.

Schmid, R. \& MAHLER, R. (1959) Chronic progressive myopathy with myoglobinuria: demonstration of a glycogenolytic defect in the muscle. Journal of Clinical Investigation, 38, 2044.

\title{
Acute onset diabetes due to an ACTH secreting oat cell carcinoma of the bronchus
}

\author{
Norman G. SOLER \\ M.D., Ph.D., M.R.C.P.
}

\section{General Hospital, Birmingham, B4 6NH}

\begin{abstract}
Summary
Diabetes of acute onset led to this patient's referral to hospital. Following investigation, it became apparent that the diabetes was only part of the wider clinical picture produced by an ACTH secreting oat cell carcinoma of the bronchus.
\end{abstract}

DiabeTES, which is secondary to other diseases, is quite commonly seen. However, diabetes of acute onset due to ACTH production by an oat cell carcinoma of the bronchus is a distinctly uncommon presentation. Cushing's disease occurs in between $0.5 \%$ and $2 \%$ of bronchial carcinomas (Azzopardi, Freeman \& Poole, 1970; Ross, 1966) and diabetes may be one of the features of its variable clinical effects (Bayliss, 1971). In the present case, clinical evidence of adrenal cortical over-activity appeared before the underlying malignant tumour had been diagnosed and the patient was referred to hospital with a diagnosis of diabetes.

\section{Case report}

A 66-year-old man had an appointment at the diabetic clinic, but due to the urgency of his symptoms, the general practitioner decided to ask for an emergency admission to hospital. His main complaints were thirst and polyuria for the last 7 days and he had heavy glycosuria. There was also a history of increasing shortness of breath for the past 2 years. Although this symptom had been investigated 18 months previously with an X-ray chest and an ECG, a diagnosis had not been reached. He had smoked 20 cigarettes a day all his life and shortness of breath did not alter his habits.

Clinical examination showed an ill, drowsy, dehydrated man with a pigmented facial appearance. He had bilateral ankle oedema, but no finger clubbing or enlarged lymph glands. His pulse was feeble and irregular and his blood pressure was $120 / 60 \mathrm{mmHg}$. There were no murmurs over the praecordium and the breath sounds were normal with no accompaniments. In the abdomen a firm liver was palpable two fingers below the costal margin.

The initial investigations confirmed a diagnosis of diabetes mellitus as his random blood sugar result was $250 \mathrm{mg} / 100 \mathrm{ml}$. Other investigations on admission to hospital were serum $\mathrm{Na}^{+} 144 \mathrm{mEq} / \mathrm{l}$, serum $\mathrm{K}^{+} 2.5 \mathrm{mEq} / 1$, blood urea $40 \mathrm{mg} / 100 \mathrm{ml}$, pH 7.53, $\mathrm{pCO}_{2} 44$, and standard bicarbonate $35 \mathrm{mEq} / \mathrm{l}$. Total proteins $5.3 \mathrm{~g}$, albumin $3.1 \mathrm{~g}$, globulin $2 \cdot 2 \mathrm{~g}$, serum Ca $8.4 \mathrm{mg} / 100 \mathrm{ml}$, alkaline phosphatase 19 units, bilirubin $1.7 \mathrm{mg} / 100 \mathrm{ml}$ and aspartate aminotransferase (SGOT) 160. Repeated electrocardiograms showed supraventricular arrhythmias with varying atrioventricular conduction. A portable $\mathrm{X}$-ray of his chest indicated bilateral hilar gland enlargement.

Within a couple of days, despite a restricted carbohydrate intake and oral hypoglycaemic agents, his blood sugars had risen to between 300 and $400 \mathrm{mg} /$ $100 \mathrm{ml}$ and treatment with insulin became necessary. Although potassium supplements were being given, the serum potassium remained below $2.6 \mathrm{mEq} / 1$ and $24 \mathrm{hr}$ urine collections showed that he was still losing between 90 and $96 \mathrm{mEq}$ of potassium per day. He was, therefore, given an infusion of $\mathbf{2 7 0}$ $\mathrm{mEq}$ of potassium in $0.45 \% \mathrm{~N}$ saline over $36 \mathrm{hr}$ and in this way the serum potassium rose to $4.2 \mathrm{mEq} / \mathrm{l}$. At this stage the ECG reverted to sinus rhythm. Serum cortisol levels were determined on venous bloods 